\title{
Effect of lecirelin acetate, hCG or progesterone administration on day 7 post-insemination on conception rate and progesterone concentration in cross-bred cattle
}

\author{
M.S. Akhtar ${ }^{1 *}$, M. Saleem ${ }^{2}$, E. Ahmad ${ }^{1}$, T. Ahmad ${ }^{1}$, M.H. Lashari ${ }^{3}$, M.M. Ayaz ${ }^{1}$, \\ L.A. Lodhi ${ }^{4}$, I. Ahmad ${ }^{4}$, I. Hussain ${ }^{1}$ and M. Akhtar ${ }^{1}$
}

${ }^{1}$ Faculty of Veterinary Sciences, Bahauddin Zakariya University, Multan, ${ }^{2}$ Department of Animal Sciences, Allama Iqbal Open University, Islamabad, ${ }^{3}$ Department of Life Sciences, Islamia University, Bahawalpur, ${ }^{4}$ Faculty of Veterinary Sciences, University of Agriculture, Faisalabad, Pakistan, ${ }^{*}$ Corresponding author: Email: drsaleemakhtar@bzu.edu.pk.

(Received December 22, 2017; Accepted February 25, 2018)

\begin{abstract}
The present study was designed to evaluate the effect of administration of lecirelin acetate, hCG and progesterone after AI on ovarian picture, serum progesterone concentrations and first service conception rate in cross-bred cattle. A total of 160 lactating cross bred (Friesian x Sahiwal) cattle were divided into 4 groups after AI. The groups were treated as follows: control (injected i.m with normal saline $2 \mathrm{ml}, \mathrm{n}=40$ ), d 7-LA (injected i.m with lecirelin acetate $100 \mu \mathrm{g}, \mathrm{n}=40$ ), $\mathrm{d}$ 7-hCG (injected with hCG $3300 \mathrm{IU}, \mathrm{n}=40$ ) and $\mathrm{d} 7-\mathrm{P}_{4}$ (injected i.m with Progesterone $0.5 \mathrm{mg}$ daily for 4 days, $\mathrm{n}=40$ ) group. The hormonal treatments were given to animals on day 7 after AI. The ultrasonography and blood sampling was done before treatment and then 7 days later. All animals were examined for pregnancy through ultrasonography at $40 \pm 1$ day after AI. The diameter of SCL on 7 days after treatment was higher $(\mathrm{P}<0.01)$ in group d 7-LA and d 7-hCG group cows as compared to control cows. In contrast, the diameter of SCL in $\mathrm{d} 7-\mathrm{P}_{4}$ treated cows did not differ from control cows. Formation of ACL was observed only in $50 \%$ \& $80 \%$ cows in $\mathrm{d} 7$-LA and $\mathrm{d} 7$-hCG group respectively. No ACL was observed in control and $\mathrm{d} 7-\mathrm{P}_{4}$ cattle on day 7 after treatment. The $\mathrm{P}_{4}$ concentrations were significantly higher $(\mathrm{P}<0.01)$ in $\mathrm{d} 7$-hCG treated cattle as compared to control at 7 days after treatment. As compared to 10 percent First Service Conception Rate (FSCR) in controls, an increase $(P<0.05)$ of 50 percent and 40 percent was observed in each treatment group ( $\mathrm{d}$ 7-hCG \& d 7-LA), non-significant $(\mathrm{P}>0.05)$ difference in FSCR was observed between control and d 7- $\mathrm{P}_{4}$ group. It was concluded that the use of hCG or LA, 7 days after AI is a beneficial tool to improve conception rate in cross-bred cattle whereas use of parental $\mathrm{P}_{4}$ post-breeding has no effect on SCL diameter and conception rate.
\end{abstract}

Keywords: Lacerilin acetate, hCG, Progesterone, Accessory corpus luteum, Conception rate Available online at http://www.vetmedmosul.org/ijvs

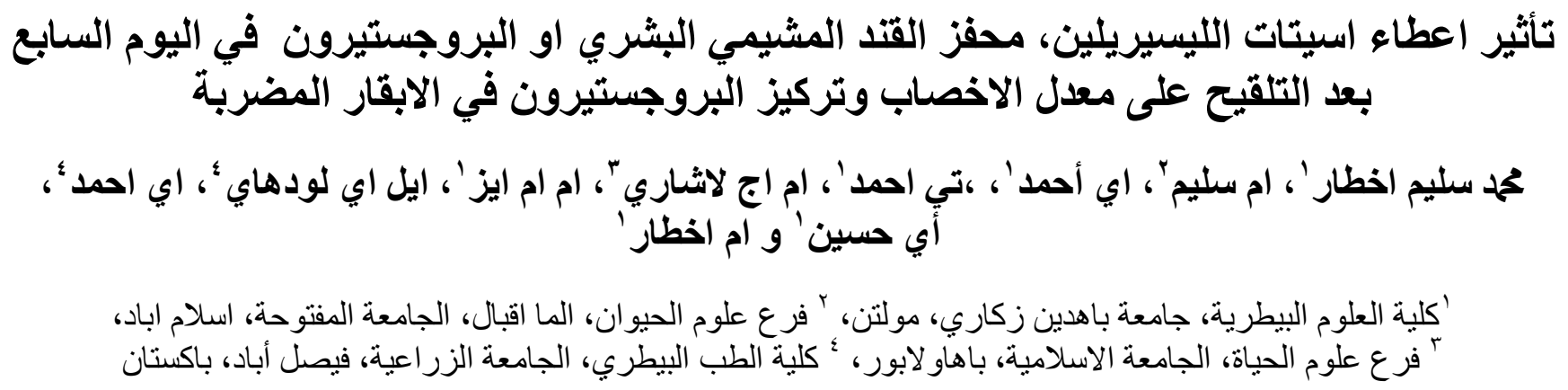

الخلاصة

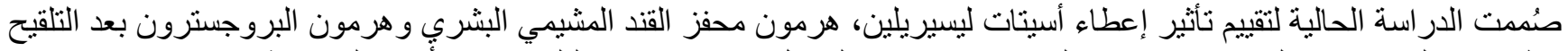

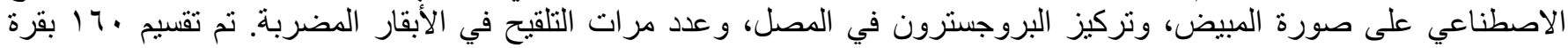


حلوب مضربة (Sahiwal X Friesian) إلى اربعة مجاميع بعد اجر اء التلقيح الصناعي. تم التعامل مع المجموعات عات على على النحو التالي:

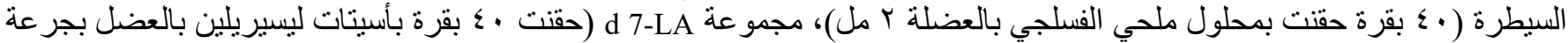

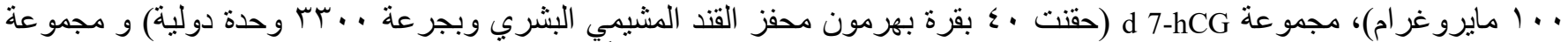

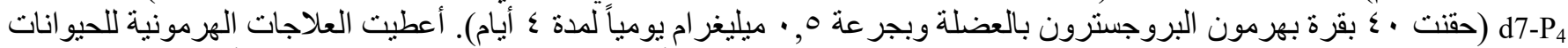

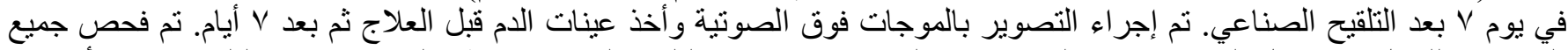

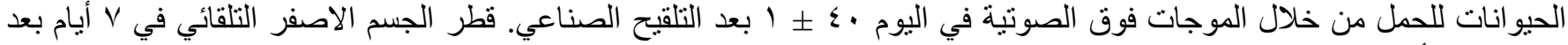

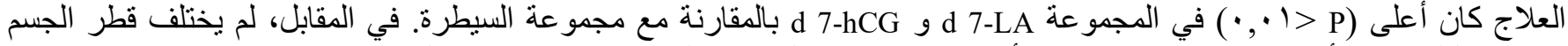

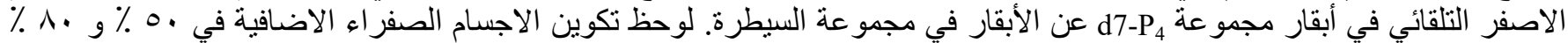

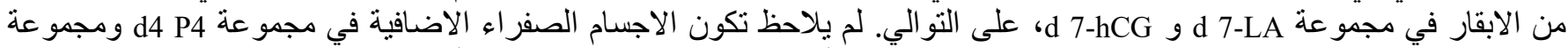

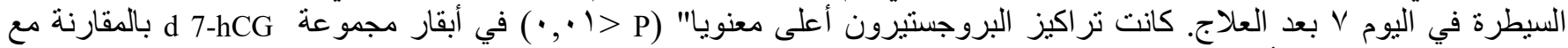

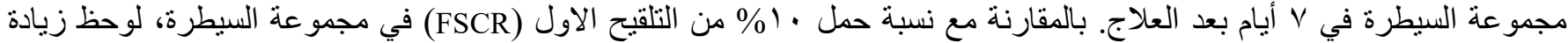

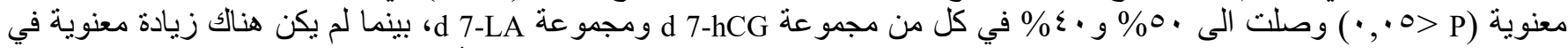

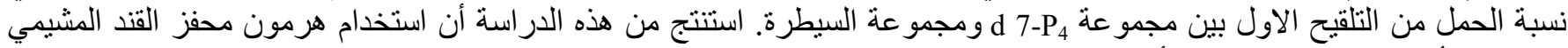

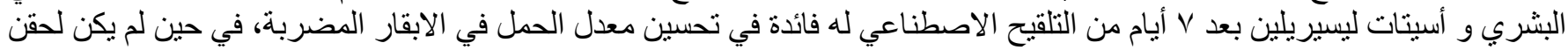
هرمون البروجستيرون بعد التلقيح ناثير على على قطر الجسم الاصفر التلقائي ومعدل الحمل.

\section{Introduction}

Efficient reproduction is important for the sustainable improvement of animal productivity and is a critical factor influencing the economic viability of livestock farmers. In developing countries, lower fertility is an important factor affecting the livestock production (1).

Conception failure is related with less than normal concentrations of progesterone $\left(\mathrm{P}_{4}\right)$ as early as day 6 after insemination (2). Embryo development is associated with concentrations of progesterone and the ability of the conceptus to secrete the anti luteolytic hormone, interferontau (3). Exogenous $\mathrm{P}_{4}$ has been shown to stimulate embryo development (4). A number of treatments could be used to increase peripheral $\mathrm{P}_{4}$ concentrations after artificial insemination (AI), that improve the function of corpus luteum (CL), or supplement progestin.

A variety of hormonal regimens have been used to improve conception rates in cattle. Modern approaches have been focused on gonadotropin releasing hormone $(\mathrm{GnRH})$ and human chorionic gonadotropin (hCG) hormones. But, their effects on conception rates are variable. Some authors reported increased conception rate in lactating dairy cattle (5-6), whereas, others have reported no effect (7-8).

Use of GnRH or its agonists (lecirelin acetate) to enhance conception rates is based on an understanding of GnRH-induced biological effects on the reproductiveendocrine system. This consequence has been brought through GnRH-stimulated LH surge and stimulating corpus luteum for $\mathrm{P}_{4}$ production (9). The use of GnRH (10-11) or hCG (12-13) after AI increases $\mathrm{P}_{4}$ secretion due to the luteotropic effect (13-14) and/or induction of an accessory corpus luteum (11-15) thus, increasing $\mathrm{P}_{4}$ concentration and, possibly, also conception. The use of $\mathrm{P}_{4}$ releasing intravaginal devices (PRID) and controlled internal drug release (CIDR) between day 6 and 12 improves conception rate has been well documented in literature (16-17). The parental use of $\mathrm{P}_{4}$ after 7 days of AI has not been studied. The present study was, therefore, designed to determine the effect of lecirelin acetate, hCG and $\mathrm{P}_{4}$ administration postbreeding in crossbred cattle.

\section{Materials and methods}

The research was conducted on 160 lactating cross bred (Friesian x Sahiwal) cows in Pakistan at a cattle farm located between Latitude $30.1984^{\circ} \mathrm{N}$ and Longitude $71.4687^{\circ} \mathrm{E}$. The animals were in 3 rd lactation and body weight of animals ranged from $312 \pm 1.70$ to $318 \pm 1.94 \mathrm{~kg}$ and milk production ranged from $7.1 \pm 0.29$ to $7.6 \pm 0.17$ liters per day. Each animal was fed cotton seed cake (1.6 $\mathrm{kg})$, wheat bran $(1.59 \mathrm{~kg})$, wheat straw $(4.55 \mathrm{~kg})$ and green fodder $(9.09 \mathrm{~kg})$ daily. All cows included in the study were in their first AI postpartum and interval from calving to treatment was above 90 days and cows were free from brucellosis, tuberculosis and mastitis. Each cow was identified by tattoo in the ear. The animals had free access to drinking water. Semen of single bull of Sahiwal breed was used for AI. All the inseminations were done by single technician. Following AI, the animals were randomly divided into four groups viz., control (normal saline $2 \mathrm{ml}$, $\mathrm{n}=40$ ), d 7-LA (lecirelin acetate $100 \mu \mathrm{g}$, Dalmeralin; Fatro, Itlay, n=40), d 7-hCG (hCG 3300 IU, Choriomon; Lugano, Switzerland, $\mathrm{n}=40$ ) and $\mathrm{d} 7-\mathrm{P}_{4}$ (Progesterone $0.5 \mathrm{mg}$ daily for 4 days, Pregtone; Selmore Pharmaceuticals, Pakistan, $\mathrm{n}=40$ ) group. The hormonal treatments were given i.m to animals on day 7 after AI. 
Ovaries of all experimental animals were scanned through trans-rectal probe (7.5 - MHz, Honda, Japan). The ultrasonography was done before treatment and then 7 days later. Blood sampling from all experimental cows was done before hormonal treatment and 7 days after treatment. Blood was collected from jugular vein with sterilized disposable syringe with $18 \mathrm{G}$ needle. The blood samples were brought to the lab in cooled box. Serum was separated by centrifugation at $3000 \mathrm{rpm}$ for 15 minutes. The serum samples were stored at $-20^{\circ} \mathrm{C}$ till analysis (18). Progesterone concentrations were measured through ELISA by using a commercially available kit (Bio Check, Inc, Lot. $\mathrm{RN}-36893)$. The sensitivity of assay was $0.2 \mathrm{ng} / \mathrm{ml}$, whereas inter and intra- assay coefficients of variation were $<15 \%$. All cows were examined for pregnancy through ultrasonography at $40 \pm 1$ day after AI. The data regarding first service conception rate (FSCR) were analyzed by Chi square test, whereas diameter of spontaneous corpus luteum
(SCL), accessory corpus luteum (ACL) and $\mathrm{P}_{4}$ concentrations were analyzed by ANOVA (19).

\section{Results}

The ovarian response in cross-bred cows for different experimental groups is summarized in Table- 1 . The diameter of SCL on 7 days after treatment was higher $(\mathrm{P}<0.01)$ in $\mathrm{d} 7$-LA and $\mathrm{d} 7$-hCG group as compared to control. In contrast, the diameter of SCL in $\mathrm{d} 7-\mathrm{P}_{4}$ did not differ from control. Since the purpose for the use of lacerilin acetate and hCG was to induce ACL during first wave of follicles at day 7 after AI. Formation of ACL was observed only in $50 \%$ \& $80 \%$ cows in d 7-LA and $\mathrm{d} 7$ hCG group respectively. ACL diameter was greater in d 7hCG cattle in comparison to d 7-LA cattle. No ACL was observed in control and $\mathrm{d} 7-\mathrm{P}_{4}$ cattle on day 7 after treatment.

Table 1: Ovarian response in cross-bred cattle treated with LA, hCG and progesterone on day 7 after AI: (SCL and ACL diameter: $\mathrm{mm}$ )

\begin{tabular}{|c|c|c|c|c|c|c|c|c|}
\hline \multirow[t]{2}{*}{ Day } & \multicolumn{2}{|c|}{ Control } & \multicolumn{2}{|c|}{$\mathrm{d} 7-\mathrm{P}_{4}$} & \multicolumn{2}{|c|}{ d 7-LA } & \multicolumn{2}{|c|}{ d 7-hCG } \\
\hline & SCL & ACL & SCL & ACL & SCL & ACL & SCL & ACL \\
\hline Day 7 & $12.6 \pm 0.4$ & - & $12.8 \pm 0.5$ & - & $12.8 \pm 0.3$ & - & $12.6 \pm 0.5$ & - \\
\hline Day 14 & $12.8 \pm 0.5$ & - & $12.9 \pm 0.5$ & - & $13.8 \pm 0.4^{*}$ & $9.2 \pm 0.3^{\mathrm{a}}$ & $14.1 \pm 0.4^{*}$ & $11.6 \pm 0.4^{\mathrm{a}}$ \\
\hline
\end{tabular}

${ }^{* \mathrm{a}}$ There was significant difference $(\mathrm{P}<0.01)$

Serum progesterone $\left(\mathrm{P}_{4}\right)$ concentrations were determined in all experimental cows at the time of treatment and 7 days later (Table- 2). In all experimental groups, the serum $\mathrm{P}_{4}$ concentrations were increased $(\mathrm{P}<0.01) 7$ days after treatment as compared with the day of treatment (Fig. 1). The $\mathrm{P}_{4}$ concentrations were significantly higher $(\mathrm{P}<0.01)$ in $\mathrm{d} 7$-hCG and d7-LA cattle as compared to control at 7 days after treatment. As compared to 10 percent FSCR in controls, an increase $(\mathrm{P}<0.05)$ of 50 percent and 40 percent was observed in each treatment group (d 7-hCG \& d 7-LA). Non-significant $(\mathrm{P}>0.05)$ difference in FSCR was observed between control and d 7$\mathrm{P}_{4}$ group.

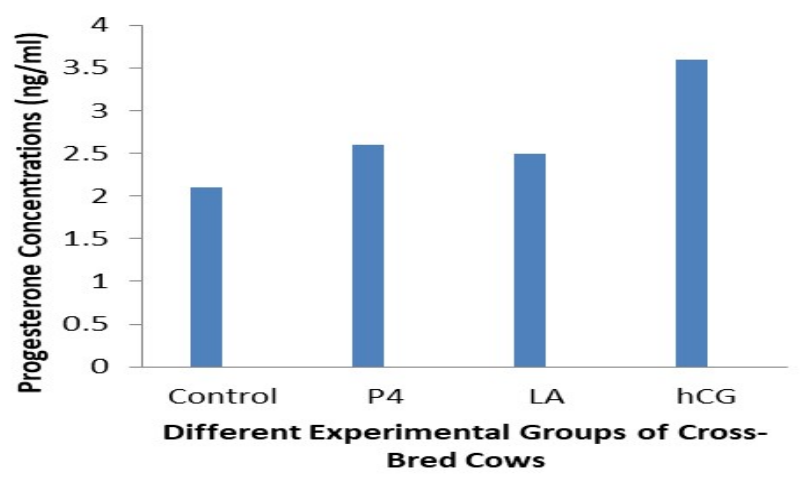

Fig. 1: Difference in serum progesterone concentrations before treatment and 7 days later in experimental cross-bred cattle.

Table 2: Serum progesterone concentrations and first service conception rate in cross-bred cattle treated with LA, hCG and progesterone on day 7 after AI

\begin{tabular}{lcccc}
\hline Progesterone Concentration $(\mathrm{ng} / \mathrm{ml})$ & Control & $\mathrm{d}$ 7-P & $\mathrm{d}$ 7-LA & $\mathrm{d}$ 7-hCG \\
\hline P4 at the time of treatment & $1.5 \pm 0.2$ & $1.4 \pm 0.4$ & $1.6 \pm 0.3$ & $1.5 \pm 0.3$ \\
P4 7 days after treatment & $3.4 \pm 0.3$ & $3.6 \pm 0.3$ & $4.7 \pm 0.3^{*}$ & $5.1 \pm 0.2^{*}$ \\
First Service Conception Rate (\%) & 10 & 10 & $40^{*}$ & $50^{*}$ \\
\hline
\end{tabular}

*There was significant difference $(\mathrm{P}<0.01)$ 


\section{Discussion}

In the present study, cross-bred cattle were treated with LA, hCG or $\mathrm{P}_{4}, 7$ days after AI to induce ACL and increase circulating progesterone concentrations. About $50 \% \& 80$ $\%$ cows develop ACL in response to LA and hCG. Development of ACL during this phase of estrous cycle is in agreement with other studies for GnRH (20) and hCG (13-21). The increase in size of SCL in response to hCG is attributed to the fact that hCG functions like LH. hCG binds with LH receptors at target site and affects on small luteal cells to secrete $\mathrm{P}_{4}$. Size of large luteal cells increased when hCG was given on day 3-5 of ovine estrous cycle (22). Since about $80 \% \mathrm{P}_{4}$ is synthesized from large luteal cells (22), therefore, in our study increase in diameter of SCL was due to increase in size of large lueal cells. Higher $\mathrm{P}_{4}$ in hCG treated cattle in our study is due to the effect of hCG on SCL as well as ACL.

Formation of ACL in response to LA is reported in another study also (21). In our study, $\mathrm{P}_{4}$ concentrations were higher in LA treated cattle than control and are in agreement with Howard et al. (23). The results of LA and hCG are comparable for development of ACL in our study, LA and hCG were equally effective in inducing CL when given on day 6 of estrous cycle in heifers (11). In our study, we replaced the use of CIDR in previous studies with daily $\mathrm{P}_{4}$ administration for 4 days. Administration of $\mathrm{P}_{4}$ (i.m) for 4 days did not increased the SCL diameter as well as serum $\mathrm{P}_{4}$ concentrations as compared with control group.

It has been reported that administration of hCG/ GnRH in early luteal phase between 4-6 day of estrous cycle induced ovulation of the first wave dominant follicle and formation of accessory CL. Higher FSCR was observed in hCG and LA cattle. These findings are in agreement with Santos et al. (13) who evaluated the effects of hCG administered on day 5 after $\mathrm{AI}$ on $\mathrm{CL}$ number, $\mathrm{P}_{4}$ concentrations, conception rate and pregnancy loss in highproducing dairy cows. The findings of present study also corroborate with Stevenson et al. (21). Daily $\mathrm{P}_{4}$ administration did not affected FSCR in present study. The $\mathrm{P}_{4}$ concentration during luteal phase after $\mathrm{AI}$ is associated with good quality embryo development (24). During the process of maternal recognition of pregnancy, high quality embryo will suppress luetlytic process through IFN. $\tau$ (2526). In our study, beneficial effect of hCG and LA was observed through improvement of SCL diameter, development of ACL and thus higher circulating $\mathrm{P}_{4}$ concentrations. It was concluded that use of hCG or LA, 7 days after $\mathrm{AI}$ is a beneficial tool to improve conception rate in cross-bred cattle. The use of parental $\mathrm{P}_{4}$ post-breeding has no effect on SCL diameter and conception rate.

\section{References}

1. Pryce JE, Nielsen BL, Veerkamp RF, Simm G. Genotype and feeding system effects and interactions for health and fertility traits in dairy cattle. Livestk Prod Sci. 1999;57:193-201.

2. Thatcher WW, Moreira F, Santos JE, Mattos RC, Lopes FL, Pancarci SM, Risco CA. Effects of hormonal treatments on reproductive performance and embryo production. Theriogenol. 2001;55:75-89.

3. Mann GE, Lamming GE. The influence of progesterone during early pregnancy in cattle. Reprod Domest Anim. 1999;34:269-274.

4. Thatcher WW, Staples CR, Danet-Desnoyers G, Oldick G, Schmidt EP. Embryo health and mortality in sheep and cattle. J Anim Sci. 1994;72:16-30.

5. Drew SB, Peters AR. The effect of treatment with a gonadotrophin releasing hormone analogue on the fertility of dairy cows. Proc Intl Cong Anim Reprod, Hague, Netherlands. 1992;3:319-326.

6. Anjum IA, Usmani RH, Tunio MT, Abro SH. Improvement of conception rate in crossbred cattle by using GnRH analogue therapy. Pak Vet J. 2009;29:93-94.

7. Ryan DP, Kopel E, Boland MP, Godke RA. Pregnancy rates in dairy cows following the administration of a GnRH analogue at the time of artificial insemination or at mid-cycle post-insemination. Theriogenol. 1991;36:367-377.

8. Coleman DA, Bartol FF, Spencer TE, Floyd JG, Wolfe D F, Brendemuehl JP. Effect of potent GnRH agonist on hormonal profiles, synchronization of estrous and fertility in beef cattle. J Anim Sci. 1991;69:396-401.

9. Gaja AO, Hamana K, Kubota C, Kojima T. Evaluation of the effect of a 3rd GnRH injection administered six days after the 2nd GnRH injection of Ovsynch on the reproductive performance of Japanese black cows. J Vet Sci. 2008;9:273-279.

10. Lewis GS, Caldwell DW, Dowlen, HH, Owen JR. Effects of gonadotropin-releasing hormone and human chorionic gonadotropin on pregnancy rate in dairy cattle. J Dairy Sci. 1990;73:66-72.

11. Schmitt EJP, Barros CM, Fields MJ. A cellular and endocrine characterization of the original and induced corpus luteum after administration of a gonadotropin releasing hormone agonist or human chorionic gonadotropin on day 5 of the estrus cycle. J Anim Sci. 1996;74:1915-1929.

12. Mancio AB, Londono Henandez FI, Fonseca FA. Fontes lipidicas dieteticas associadas humana (hCG) na funcao reprodutiva e no metabolism de lipids de novilhas. Arq Brasileri Medic Vet Zootec. 1999;51:163-170.

13. Santos JEP, Thatcher WW, Pool L, Overton MW. Effect of human chorionic gonadotropin on luteal function and reproductive performance of high-producing lactating Holstein dairy cows. J Anim Sci. 2001;79:2881-2894.

14. Kerbler TL, Buhr MM, Jordan LT. Relationship between maternal plasma progesterone concentration and interferon Tau synthesis by the conceptus in cattle. Theriogenol. 1997;47:703-714.

15. Fonseca JF, Silva Filho JM, Palhares MS. Concentracao plasm atica de progesterone em novilhas receptoras submetidas a administracao de rbST, GnRH ou hCG no quinto dia do ciclo estral. Arq Brasileri Medic Veteri Zootec. 2001;53:451-458.

16. Stevenson JS, Mee MO. Pregnancy rates of Holstein cows after postinsemination treatment with a progesterone-releasing intravaginal device. J Dairy Sci. 1991;74:3849-3856.

17. Macmillan KL, Peterson AJ. A new intravaginal progesterone releasing device for cattle (CIDE-B) for oestrus synchronization, increasing pregnancy rates and the treatment of postpartum anoestrus. Anim Reprod Sci. 1993;33:1-25.

18. Donnelly JX, Soldin SJ, Mealon DA, Hicks JM. Stability of twenty five analytes in human serum at $22{ }^{\circ} \mathrm{C}, 4{ }^{\circ} \mathrm{C}$ and $-20{ }^{\circ} \mathrm{C}$. Tediaer Pathol Lab Med. 1995;15:869-874.

19. Steel RGD, Torrie JH, Dickey DA. Principles and Procedures of Statistics. A Biometrical Approach ( $3^{\text {rd }}$ ed.). Mc Graw-Hill Publishing Co., New York, 2006. 
20. Vasconcelos JLM, Silcox RW, Rosa GJM. Synchronization rate, size of the ovulatory follicle and pregnancy rate after synchronization of ovulation beginning on different days of the estrus cycle in lactating dairy cows. Theriogenol. 1999;52:1067-1078.

21. Stevenson JS, Portaluppi MA, Tenhouse DE, Lloyd A, Eborn DR, Kacuba S, Jarnette JMD. Interventions after artificial insemination: conception rates, pregnancy survival and ovarian responses to gonadotropin-releasing hormone, human chorionic gonadotropin and progesterone. J Dairy Sci. 2007;90:331-340.

22. Niswender GD, Juengel JL, McGuire WJ, Silva PJ, Rollyson MK, McIntush EW. Mechanisms controlling the function and life span of the corpus luteum. Physiol Rev. 2000;80:2-29.
23. Howard JM, Manzo R, Dalton JC, Frago F, Ahmadzadeh A. Conception rates and serum progesterone concentration in dairy cattle administered gonadotropin releasing hormone 5 days after artificial insemination. Anim Reprod Sci. 2006;95:224-233.

24. Mann GE, Lamming GE. Relationship between maternal endocrine environment, early embryo development and inhibition of luteolytic mechanism in cows. Reprod. 2001;121:175-180.

25. Inskeep EK. Pre ovulatory, post ovulatory, and post maternal recognition effect of concentrations of progesterone on embryonic survival in the cow. J Anim Sci. 2004;82:24-39.

26. Thatcher WW, Moreira F, Pancarci SM, Bartolome JE, Santos JE. Strategies to optimize reproductive efficiency by regulation of ovarian function. Domest Anim Endocrinol. 2002;23:243-254. 